http://dx.doi.org/10.4314/jae.v17i1.2

\title{
Analysis of farmers' adaptation strategies to climate change in cocoa production in Kwara State
}

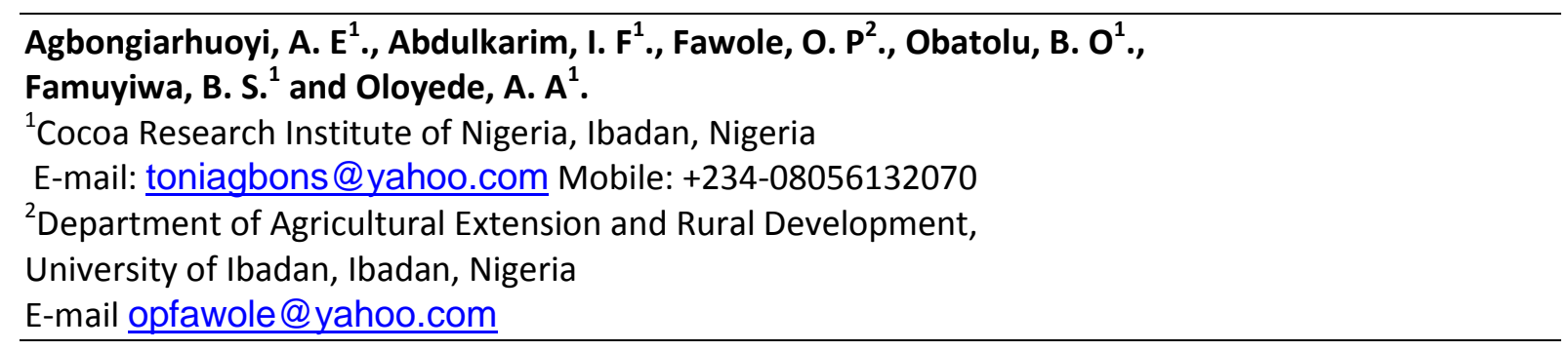

\begin{abstract}
Changing climate and weather patterns are predicted to have severe negative impacts on food production, food security and natural resources in the immediate and coming years. Climate change alters the development of cocoa pods, insect pests and pathogens which translate into lower crop yields and impact farm income. This study examined the climate change adaptation strategies of farmers on cocoa production practices. A multi-stage random sampling procedure was used to select 60 cocoa farmers from three out of eight Local Government Areas (LGAs) producing cocoa in Kwara State. Interview schedule was used in data collection and analyzed with descriptive statistics and correlation analysis. The results reveal that $60.7 \%$ of the farmers were male. Majority (59.9\%) of the farmers were between middle and old age with farming experience of 21-30 years and farm size of mainly between 0.4-2.7 hectares. Most farmers (85\%) observed an extension beyond the normal dry months of November to February. This situation could have some implications on cocoa production. The main climate change strategies adopted by farmers include praying for rain (86.7\%), use of improved varieties, (81.7\%), climate prediction $(76.7 \%)$, changes in cropping pattern and agro-forestry (75\% each), control of soil erosion (73.3\%) and fertilizer application (60\%). Inadequate irrigation, $41.7 \%$ and crop diversification, 36.7\%; constituted minor strategies. The cocoa production practices still adopted were weeding, 98.3\%; seedling planting, 96.7\%; insect pest and diseases control, 95\%; bush clearing, 93.3\%; fermentation and drying, 91.7\%; tree felling, 88.4\%; pruning, 85\% and burning before planting, 70\%. However, Pearson product moment correlation coefficient (PPMC) showed that a significant relationship existed between age of cocoa farm (0.016) and cocoa production practices at $P<$ 0.05 . Cocoa farmers' climate change strategies $(0.121)$ were not statistically related with cocoa production practices at $P<0.05$. Most of the strategies and practices currently used by farmers should be improved upon to ensure appropriate agronomic practices and adaptation to changes in climate.
\end{abstract}

Keywords: Climate change, adaptation, cocoa production practices, farmers

\section{Introduction}

Cocoa played a significant socio-economic role in Nigeria. It accounts for about $2 \%$ of the national export earnings and over 200,000 rural households in 14 Cocoaproducing states depend on cocoa for the majority of their cash income (National Cocoa Development Committee NCDC, 2008). Across the supply chain millions more are involved in trade, transport, processing and export. They are dependent on 


\section{Journal of Agricultural Extension}

Vol. 17 (1) June, 2013

ISSN 1119-944X

cocoa for their livelihoods. Cocoa beans are used in the production of cocoa powder, chocolate products, beverages, wine and butter. Also, cocoa is used to produce cocoa bread, biscuits, soap, cream, livestock feeds among others (Arueya1989, Olubamiwa et al, 2000 and Hamzat et al, 2003).

Nigeria used to be the second leading producer in the world, but due to a combination of factors its production has dwindled over time. Nigeria is currently the fourth largest producer of cocoa after Cote d'ivoire, Ghana and Indonesia, (ICCO, 2009/2010). According to Ayanlaja (2000) cocoa production vied from 310,000 tonnes despite increase in land area, insecticide application and introduction of high yielding F3 Amazon varieties. The causes of decline in production have been attributed to the oil boom, which led to the neglect of cocoa due to a shift in labour from cocoa farms to the industrial sectors (Ayoola, et-al 2000). Also, there are issues of aged cocoa trees, old age of farmers, poor agricultural practices and climate change.

Climate is very important in agriculture. Climate sets the limit for the agricultural activity in any area or ecological zone of the world. The major components of climate which interact to produce the local weather are temperature, rainfall, humidity, photo-period and altitude (Opeke, 2005). Cocoa production is highly sensitive to change from length and intensity of sunshine, to rainfall and water application, soil condition and temperature due to evapo-transpiration effects. It has been reported widely that climate change also plays a major role in altering the development of cocoa pests and pathogens and shifting their interactions (Oyekale et al, 2009). This translates into lower crop yields, which in turn impact income and livelihood. Also, it was reported by Mpako et-al, (2008) that some years came with adequate rainfall but most people fail to maximize the opportunity because of the confusion in rainfall patterns.

Unfortunately, recent rainfall patterns have been either excessive, resulting in a high incidence of black pod disease and yield losses, or insufficient leading to high seedling mortality and poor yields in terms of annual rainfall. Enete and Amusa, (2010) reported that climate change is one of the most serious environmental threats facing mankind worldwide. It affects agriculture in several ways; including its direct impact on food production which is attributable to the natural climate cycle and human activities has adversely affected agricultural production in Africa (Ziervogel et-al, 2006). Available evidence shows that climate change is global, likewise its impacts, but the most adverse effect will be felt mainly by developing countries, especially those in Africa due to their low level of coping mechanisms in such countries (Odjugo, 2010). As the planet warms, rainfall patterns shifts and extreme events such as droughts, floods and forest fires become more frequent (Zoellick, 2009), which results in poor and unpredictable yields, thereby making farmers more vulnerable, particularly in Africa (UNFCCC, 2007).

Adaptation to climate change involves taking action to reduce either the negative effects or to capitalize on the positive effects of climate change (Anim-kwapong, et-al 2003). The Inter-governmental Panel on Climate Change (IPCC) (2007) describes climate change adaptation as an adjustment to or interventions, which take place in order to mange the losses or take advantage of the opportunities presented by a changing climate. Adaptation to climate change in cocoa production and other 


\section{Journal of Agricultural Extension}

Vol. 17 (1) June, 2013

ISSN 1119-944X

agricultural management practices in response to changes in climate conditions involves a combination of various individual responses at the farm-level and assumes that farmers have access to alternative practices and technologies available in their areas of production. Some of these important adaptation options as documented in literature include crop diversification, mixed cropping, livestock farming system, using different crop varieties, changing planting and harvesting dates, mixing less productive drought resistant varieties and high yield water sensitive crops (Jagtap, 1995).

Agricultural adaptation involves two types of modification in production systems. The first is increased diversification that involves engaging in production activities that are drought tolerant and or resistant to temperature stress as well as activities that make efficient use and take full advantages of prevailing water and temperature conditions, among other factors. Crop diversification in cocoa and non-cocoa sub-sectors can serve as insurance against rainfall variability as different crops are affected differently by climate events.

The second strategy focuses on crop management practices geared towards ensuring that critical crop growth stages do not coincide with very harsh climate condition such as mid-season droughts, crop management practices that can be used include modifying the length of growing period and changing planting and harvesting dates.

In Nigeria, the discovery and exploitation of petroleum, led to the decline in the importance attached to cocoa production and other crops. The cocoa sub-sector is not receiving much attention for it to maintain its leading role as non-oil export crop. This situation is further implicated by the behaviour and changes of global climatic variables which tend to reduce cocoa production due to its negative impact. Adaptations to these changes by cocoa farmers have become necessary in view of its implications for production and sustainability of cocoa.

This paper provides insight into those strategies cocoa farmers use in adapting to the global problem caused by climate change in Kwara State. This is important because adaptation to climate change is expected to present a heightened risk, new combinations of risks and potentially grave consequences, particularly in Kwara state Nigeria due to its direct dependence on rain fed agriculture.

\section{Objectives of the study}

The main objective of the study is to examine the climate change adaptation strategies of farmers on cocoa production practices in Kwara State Nigeria. The specific objectives were to:

1. determine the climate change adaptation measures of cocoa farmers,

2. identify the periods of dry months of the year that are becoming longer or shorter for cocoa production and

3. examine the cocoa production practices of farmers in the study area. 


\section{Hypotheses}

$\mathrm{H}_{\mathrm{Oi}}$ : There is no significant relationship between farmers' personal characteristics and cocoa production practices in the study area.

$\mathrm{H}_{\text {Oii }}$ : There is no significant relationship between climate change adaptation strategies of farmers and cocoa production practices.

\section{Methodology}

The study was conducted in Kwara state of Nigeria. Kwara state lies within the North central geopolitical zone of Nigeria. It is located between latitudes $7^{0} 45^{\prime} \mathrm{N}$ and $9^{0} 30^{\prime} \mathrm{N}$ and longitudes $2^{0} 3^{\prime} \mathrm{E}$ and $6^{0} 25^{\prime} \mathrm{E}$. The annual rainfall ranges between $1000 \mathrm{~mm}$ and $1500 \mathrm{~mm}$. Average temperature ranged between $30^{\circ} \mathrm{C}$ and $35^{\circ} \mathrm{C}$ (Kwara State ADP, 1996). The major occupation of people in the area is cultivation of cash crops with cocoa being the main crop, but often intercropped with cashew, oil palm, plantain, banana and kola. Also, food crop like maize, beans yam, sorghum and vegetable are cultivated (Yusuf, 2000).

The study made use of multi-stage sampling procedure. Cocoa is produced in eight local Government Areas of Kwara State. These include: Asa, Isin, Ifelodun, Irepodun, Oke-Ero, Ekiti, Offa and Oyun (Kwara State Ministry of Agriculture, 2011). Three out of the eight LGAs (Irepodun, Isin and Oke Ero) well noted for cocoa production were chosen. In the next stage, 24 farmers were selected from two villages in Irepodun, 20 farmers from two villages in Isin and 16 farmers from two villages in Oke-Ero LGAs due to their level of production. A total of sixty cocoa farmers were randomly selected across the three LGAs based on their predominance in cocoa production. Interview schedule was used in data collection.

The study provided information on the socio-economic characteristics of the cocoa farmers, farm size, climate change adaptation strategies adopted by farmers with respect to cocoa production practices. Descriptive statistics and Pearson product moment correlation co-efficient (PPMC) were used in the analysis. Cocoa production practices were measured using three categories by scoring: Not practiced 0 , practicing but stopped 1 , still practicing 2 . The scores were pulled together and correlated against climate change adaptation strategies of farmers.

\section{Results and Discussion}

\section{Personal characteristics of cocoa farmers}

The results in Table 1 show that $66.7 \%$ of the farmers were males while $33.3 \%$ were females. It means that more males were more involved in cocoa production in the study area. Adetunji et al, (2007) reported that men actively participate in cocoa production than the female cocoa farmers. Majority $(59.9 \%)$ of the cocoa farmers were between 55-64 years old with a mean age of 49 years which implies that semi aged and aged persons are engaged in cocoa production. Uwagboe et al, (2010), Iremiren, (2011) and CTA Agritrade (2012) reported that those into cocoa production in Nigeria are mainly old farmers over 60 years. This is seen as a factor that will hold back government efforts to promote a tripling of cocoa production especially during 


\section{Journal of Agricultural Extension}

Vol. 17 (1) June, 2013

ISSN 1119-944X

this period of climate change. On the years of farming experience, $35 \%$ of the farmers had 21-30 in cocoa production. Most of the farmers had some form of education: primary $30 \%$, secondary $15 \%$ and tertiary $28.3 \%$. Long years of farming and education will facilitate adaptation and better production practices. The farm sizes of farmers $(65 \%)$ were between $0.4-2.7$ hectares with a mean of 2.59 hectares. This is a reflection of small holdings common among Nigerian and West African cocoa farmers. Anim-kwapong and Frimpong, (2003) and Oluyole and Sanusi, (2009) confirm it that most cocoa farmers own small farm sizes. Most $(61.0 \%)$ of cocoa farms of farmers were more than 28 years of age. It is an indication of aging cocoa trees that needs rehabilitation. This will further be implicated by the possible impacts of climate change on cocoa trees because old age could reduce production and yield. Studies carried out by Gro-Cocoa, (2008), Adeogun, et al (2010) and Iremiren, (2011) corroborate this result that most cocoa farms in Nigeria are old with low productivity.

Table 1

Distribution of personal characteristics of cocoa farmers

\begin{tabular}{|c|c|c|}
\hline Variables & Percentage $(\mathrm{n}=60)$ & Mean \\
\hline \multicolumn{3}{|l|}{ Gender } \\
\hline Male & 66.7 & \\
\hline Female & 33.3 & \\
\hline \multicolumn{3}{|c|}{ Age of cocoa farmers (years) } \\
\hline $20-28$ & 16.7 & \\
\hline $29-37$ & 5.0 & \\
\hline $38-46$ & 6.7 & \\
\hline $47-55$ & 31.6 & 49.1 \\
\hline $56-64$ & 28.3 & \\
\hline $65-73$ & 11.7 & \\
\hline \multicolumn{3}{|c|}{ Farming experience (Years) } \\
\hline $1-10$ & 23.3 & \\
\hline $11-20$ & 28.3 & \\
\hline $21-30$ & 35.0 & 20.40 \\
\hline $31-40$ & 10.0 & \\
\hline $41-50$ & 3.3 & \\
\hline \multicolumn{3}{|c|}{ Educational status } \\
\hline None & 26.7 & \\
\hline Primary & 30.0 & \\
\hline Secondary & 15.0 & \\
\hline Tertiary & 28.3 & \\
\hline \multicolumn{3}{|c|}{ Farm size (Hectares) } \\
\hline $0.4-1.5$ & 41.7 & 2.59 \\
\hline $1.6-2.7$ & 23.3 & \\
\hline $2.8-4.0$ & 21.7 & \\
\hline $4.1-5.0$ & 3.3 & \\
\hline 5.1 and above & 10.0 & \\
\hline \multicolumn{3}{|c|}{ Age of cocoa farms (Years) } \\
\hline $3-15$ & 27.0 & \\
\hline $16-28$ & 33.0 & 25.9 \\
\hline $29-41$ & 28.0 & \\
\hline $42-54$ & 7.0 & \\
\hline 55 and above & 5.0 & \\
\hline
\end{tabular}

Field survey, 2011 


\section{Climate change adaptation strategies of farmers in cocoa production}

Figure 2 reveals that the major climate change strategies adopted by cocoa farmers include praying for rain $(86.7 \%)$, use of improved varieties $(81.7 \%)$, climate predicting $(76.7 \%)$, changes in cropping pattern $75 \%$ and use of agro-forestry $75 \%$. Others were control of soil erosion $73.3 \%$ and fertilizer application $60 \%$. The use of irrigation facilities (41.7\%) and crop diversification (36.7\%) were however minor strategies of farmers. From this finding it is clear that the farmers are already involved in proactive measures for copping with possible challenges of climate change which is affecting all crops including cocoa. The high adaptation could be attributed to farmers' educational level and the importance farmers placed on cocoa production. It is not surprising that cocoa farmers relied on prayers to God for rainfall and predicting climate change because most people call on God for solutions to problems at difficult times in Nigeria and West Africa. This is an indigenous measure which is not scientific but Lumala, (2008) attested to this in a study where farmers used different means to know the beginning and end of rain and future events. Bradshaw et al (2004) and Ngigi (2009) reported most of these adaptation options as part of measures used in climate change. However, the low adoption of irrigation calls for serious attention since shortage of rainfall could make cocoa to be vulnerable to the impacts of climate change. Nigerian agriculture is almost entirely rain-fed and hence inherently susceptible to the vagaries of weather. Most farmers do not have access to irrigation inputs. In line with this result, Madu, et al (2010) and Ozor and Nnaji (2010) reported that Nigeria has not developed adequate irrigation facilities for farming. The consequences are that the increasing frequency and severity of droughts especially in cocoa farms are likely to cause crop failure, low income and poverty among producers of cocoa. 


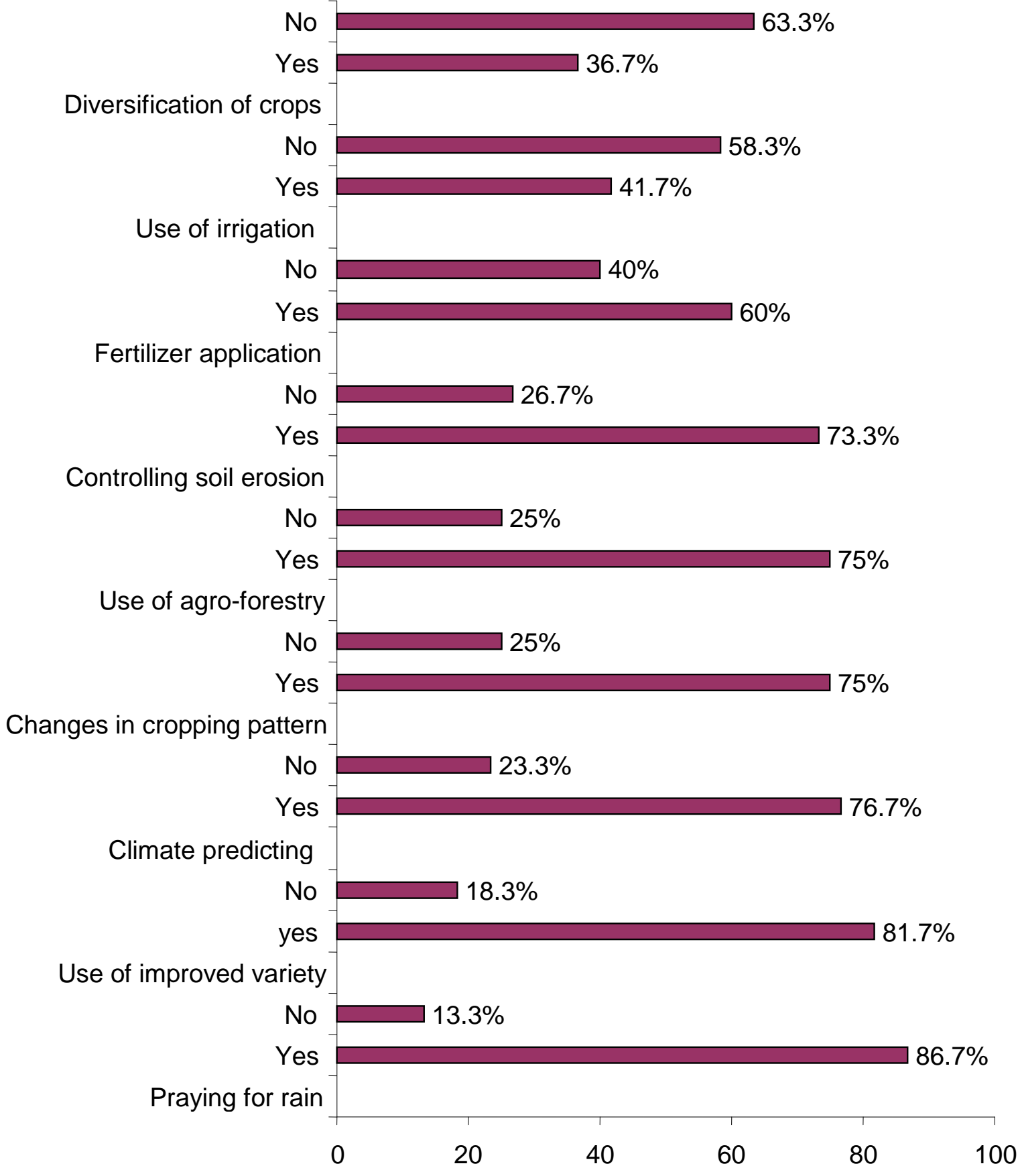

Figure 2: Cocoa farmers' adaptation strategies

Field survey, $2011 \quad(n=60)$

\section{Cocoa production practices of farmers}

In Table 2, the main cocoa production practices still adopted by farmers were weeding 98.3\%, seedling planting 96.7\%, pests and diseases control 95\%, bush clearing $93.3 \%$, fermentation and drying $91.7 \%$. Others include tree felling $88.4 \%$, 


\section{Journal of Agricultural Extension}

Vol. 17 (1) June, 2013

ISSN 1119-944X

pruning $85 \%$, and burning before planting $70 \%$. It means that almost all farmers carry out these practices which, is an indication of Good Agricultural Practices but this may not necessarily translate to how the practices are applied. It was observed that most farmers engage in firing the debris in their farms before planting. This is a traditional practice which contributes to climate change in the environment. There may be need to sensitize farmers to reduce burning operation so as to reduce the gas emissions going into the atmosphere trapping heat and causing global warming. Also, burning exposes the land to soil erosion and reduces organic matter. Medugu, (2009) opined that the activities of bush burning could increase the concentrations of green house gases that could lead to climate change.

Table 2

Distribution of farmers' cocoa production practices $(n=60)$

\begin{tabular}{lll}
\hline Cocoa production practices & Frequency & Percentage \\
\hline Weeding & & \\
Not practiced & 1 & - \\
Stop practicing & 59 & 98.3 \\
Still practicing & & \\
Seedling planting & 1 & 1.7 \\
Not practiced & 1 & 1.7 \\
Stop practicing & 58 & 96.7 \\
Still practicing & & \\
Pests and diseases control & 3 & 5.0 \\
Not practiced & - & - \\
Stop practicing & 57 & 95.0 \\
Still practicing & & \\
Bush clearing & 2 & 3.3 \\
Not practiced & 2 & 3.3 \\
Stop practicing & 56 & 93.3 \\
Still practicing & & \\
Fermentation and drying & 3 & 5.0 \\
Not practiced & 2 & 3.3 \\
Stop practicing & 55 & 91.7 \\
Still practicing & & \\
Tree felling & 5 & 8.3 \\
Not practiced & 2 & 3.3 \\
Stop practicing & 53 \\
Still practicing & & 88.3 \\
Pruning & Not practiced & \\
Stop practicing & 5 & 8.3 \\
Still practicing & 4 & 6.7 \\
Burning before planting & 51 & 85.0 \\
Not practiced & & \\
Stop practicing & 13 & 21.7 \\
Still practicing & 5 & 8.3 \\
Fied suvey, & 42 & 70.0 \\
\hline 1 & &
\end{tabular}

Field survey, 2011 


\section{Months of dry periods in cocoa production}

The findings in the study showed that 85 percent of the farmers observed an extension beyond the normal dry months of November to February while $15 \%$ indicated that there was no extension beyond dry months. The months of dry periods were longer than short periods. This is an indication of drought which is usually experienced during dry season. It affects the young and old cocoa trees. Most cocoa trees suffer serious water stress during this period when they are not irrigated. It therefore means that in order to boost cocoa production during dry periods there is need for irrigation water to be supplied to cocoa farms to reduce drought associated with climate change.

\section{Correlation of some farmers' personal characteristics and cocoa production practices}

Pearson product moment correlation coefficient (PPMC) in table 3 revealed that a significant relationship existed between age of cocoa farm (0.016) and cocoa production practices at $p<0.05$. As the cocoa farm is aging, the production practices will be more carried out by farmers so as to get good yield and income. It is a statement of fact as documented by Adeogun, et al (2010) and Iremiren, (2011) that most cocoa farms in Nigeria are old. Aging cocoa trees coupled with problems of bad weather could result in poor yield.

\section{Table 3}

Correlation analysis of farmers' personal characteristics (Age of farmer, experience, farm size and age of cocoa farm) and cocoa production practices

\begin{tabular}{lll}
\hline Variables & $\mathbf{r}$ & $\mathbf{p}$ \\
\hline Age of farmer & -0.194 & 0.164 \\
Experience & -0.204 & 0.128 \\
Age of cocoa farm & 0.309 & $0.016^{\star *}$ \\
Farm size & 0.115 & 0.382 \\
\hline
\end{tabular}

Field survey, 2011

Correlation of cocoa farmers' climate change adaptation strategies and cocoa production practices

In table 4, there was positive relationship between farmers' climate change strategies and cocoa production practices. However, the result was not statistically significant when cocoa farmers' climate change strategies were correlated with cocoa production practices. This may be due to the same practices carried out by almost all the farmers in the study area. 
Correlation analysis of cocoa farmers' climate change adaptation strategies and cocoa production practices $(n=60)$

\begin{tabular}{lll}
\hline Variables & $\mathbf{R}$ & $\mathbf{p}$ \\
\hline Cocoa farmers' climate change & 0.203 & $0.121^{*}$ \\
adaptation strategies vs cocoa & & \\
production practices & & \\
\hline
\end{tabular}

*Not significant

Field survey, 2011

\section{Conclusion}

The main strategies engaged by farmers in mitigating the impacts of climate change on cocoa production in the study area were praying for rain, use of improved varieties, climate forecasting, changes in cropping pattern, agro-forestry use, control of soil erosion and fertilizer application. Inadequate irrigation and crop diversification constituted farmers' minor strategies. Low application of irrigation will limit production because the dependence on rain fed agriculture is implicated when juxtaposed with longer periods of dry months been observed in farmers' plots. The production practices hitherto well adopted with respect to climate change include weeding, seedling planting, pests and diseases control, bush clearing, fermentation and drying, tree felling, pruning, and burning before planting. The old age of cocoa farmers and trees predicts low productivity if the farms are not rejuvenated. There is need for sustainable cocoa rehabilitation programme as a measure of adapting to possible challenges of climate change. Most of the strategies and practices currently used by farmers should be improved upon to ensure appropriate agronomic practices and adaptation to changes in climate. Private and public sectors' intervention in assisting cocoa farmers with small-scale irrigation facilities should be provided to enhance water availability especially during drought. These will boost production and inherent threats posed by climate change in the study area.

\section{Acknowledgement}

The Executive Director/Chief Executive officer of Cocoa Research Institute of Nigeria is also acknowledged for his permission granted to publish this work.

\section{References}

Adetunji, M. O., Olaniyi, O. A., and Raufu, M. O. (2007). Assessment of benefits derived by cocoa farmers from cocoa development unit activities of Oyo State. Journal of Human ecology, Vol. 22, No. 3, Pp. 212-214.

Adeogun, S.O., Olawoye, J.E. and Akinbile, L.A. (2010). Information sources to cocoa farmers on cocoa rehabilitation techniques (CRTs) in selected states of Nigeria. Journal Media and communication studies, Vol. 2, No.1, Pp. 009015.

Anim-kwapong, G.J and E.B Frimpong (2008). Vulnerability and adaptation assessment under the Netherlands climate change studies assistance 


\section{Journal of Agricultural Extension}

Vol. 17 (1) June, 2013

ISSN 1119-944X

programme phase 2 (NCCSAP2) Vulnerability of agriculture to climate change- impact of climate change on cocoa production. p. ii-v. http://www.nlcap.net/fileadmin/NCAP/Countries/Ghana/ Accessed 09 January, 2012.

Arueya, G.L. (1989). Production of soap and other industrially useful substances from cocoa and kola waste. Annual Report of the Cocoa Research Institute of Nigeria, Ibadan, Nigeria. P.94.

Ayanlaja, S.A. (2000). The development of an alley cropping system: a viable agroforestry technology for sustained cocoa production in Nigeria. Cocoa Growers' Bulleting, No. 52, Pp. 9-18.

Ayoola, B. Fasina, K.B., and Aikpokpodion, P. (2000). Development of the Nigerian cocoa industry: current issues and challenges for research and production. Proceedings of the 13th International Cocoa Research Conference Sabah, Malaysia. Pp 1367-1373.

Bradshaw B., H. Dolan, and B. Smit. 2004. Farm-level adaptation to climatic variability and change: Crop diversification in the Canadian Prairies. Climatic Change, No. 67, Pp.119-141.

CTA Agritrade (2012). Impact of climate change on cocoa production in West Africa Online @ http://agritrade.cta.int/en/content/view/full/8185. Accessed 09 January, 2012.

Enete, A.A. and Amusa, T.A. (2010)._Challenges of Agricultural Adaptation to climate change in Nigeria: A synthesis from the literature. Field Actions Science reports [Online], Vol.4, online since 20 December 2010, http://www.factsreports.revues.org/678. Accessed 3rd January, 2012. Pp. 155.

Gro-cocoa Global Research on Agriculture Newsletter (2008).Cocoa rehabilitation in Nigeria. No. 14 December, 2008. Pp. 3-5.

Hamzat, R.A; Umana, T.E. and Babayemi, O.J. (2003). Potentials of cocoa Husk pulp as a sole Feed Ingredient for African giant Land Snails (Archachatina marginata). P.151. In Book of Abstracts of the $14^{\text {th }}$ International Cocoa Conference. Organised by the Cocoa Producer's Alliance (COPAL) with the Government of Ghana, Accra. $13^{\text {th }}-18^{\text {th }}$ October.

ICCO Quarterly Bulletin of Cocoa Statistics (2009/2010). Vol. XXXVI, No. 4, Cocoa year 2009/2010. www.icco.org Accessed 22 ${ }^{\text {nd }}$ November, 2011.

ICCO Document (2012). Growing cocoa. www.icco.org/aboutgrowing/aspx Accessed $8^{\text {th }}$ January, 2012

IPCC. (2007). IPCC 4th Assessment Report - Climate Change 2007. Working Group II on "Impacts, Adaptation and Vulnerability". http://www.ipcc-wg2.org 


\section{Journal of Agricultural Extension}

Vol. 17 (1) June, 2013

ISSN 1119-944X

Iremirem, G.O. (2011). Soil fertility and ageing cocoa farms in Nigeria. A paper presented in World cocoa foundation. http://www.worldcocoafoundation.org/who-we-are/partnershipmeetings/documents//remirenPresentationPDF.pdf. Accessed 2nd January, 2012.

Jagtap, S.S. (1995). Discovery and innovation changes in Annual, Seasonal and Monthly Rainfall in Nigeria and consequences to Agriculture. J. Afr. Acad. Sci., 7(4) pP. 311-426.

Kwara state Agricultural Development Project KWADP (1996). Agronomic survey Report, llorin.

Kwara State Ministry of Agriculture, (2010). Kwara State Dairy for 2011.

Madu, D.B., Gundiri, M.N., Musa, I.K., Nwa, E.U., Adamu, M.S., Bala, M.S., Jada, A., Musa, I.K and Ogunniyi, E.O. (2010). Country Profile-Nigeria. Abuja: Ministry of Water Resources.

Medugu, N. I. (2009). Nigeria: Climate Change - A Threat to the Country's Development. http://www.allafrica.com/nigeria

Mpako, J. and Ngome, I. (2009). Climate change and cocoa production in Cameroon: Farmers' experiences and livelihood implications http://www.africafiles.org/article.asp January 2009.

National Cocoa Development Committee NCDC (2008). A handbook of the 4th National Cocoa day held in Akure, Ondo State . Published by NCDC. p.6

Ngigi, S.N. (2009). Climate Change Adaptation Strategies: Water Resources Management Options for Smallholder Farming Systems in Sub-Saharan Africa. The MDG Centre for East and Southern Africa, The Earth Institute at Columbia University, New York. Online @ www.rockfellerfoundation.org

Odjugo, P. A. O. (2010). General Overview of Climate Change Impacts in Nigeria. Journal Hum Ecol, 29(1): 47-55.

Olubamiwa, O., Odewumi, W.O., Longe, O.G and Hamzat, R.A. (2000). Practical Inclusion of Cocoa bean Shell in poultry feeds: A Preliminary Report. Pp. 981986, In Proceedings of the $13^{\text {th }}$ International Cocoa Research Conference. Organised by Cocoa Producer's Alliance with the Government of Malaysia. $9^{\text {th }}-14^{\text {th }}$, October.

Oluyole, K. A. and Sanusi, R.A. (2009). Socio-Economic Variables and Cocoa Production in Cross River State, Nigeria. J Hum Ecol, 25(1) Pp. 5-8 2009.

Opeke, L.K. (2005). Tropical Commodity tree crops. Spectrum books Ltd., Ibadan. Pp. 89-91, 96-98. 


\section{Journal of Agricultural Extension}

Vol. 17 (1) June, 2013

ISSN 1119-944X

Oyekale A.S., Bolaji, M.B. and Olowa, O.W. (2009). The effect of climate change on Cocoa production and Vulnerability Assessment in Nigeria. Agricultural Journal, Vol. 4 issue 2, Pp.77-85.

Ozor, $\mathrm{N}$ and Nnaji (2010). Difficulties in adaptation to climate change by farmers in Enugu State, Nigeria. Journal of Agricultural Extension, Vol. 14 (2), Pp, 106122. December 2010.

Thornton, P.K., Jones, P.G., Owiyo, T., Kruska, R.L., Herrero, M., Kristjanson, P., Notenbaert, $\mathrm{A}$. Bekele $\mathrm{N}$ and Omolo $\mathrm{A}$, with contributions from Orindi $\mathrm{V}$, Otiende B, Ochieng A, Bhadwal S, Anantram K, Nair S, Kumar V and Kulkar $U$ (2006). Mapping climate vulnerability and poverty in Africa. Report to the Department for International Development, ILRI, Nairobi, Kenya. P.10.

Uwagboe, E.O., Ndagi, I., Agbongiarhuoyi, A. E., Adebiyi, S., and Aigbekaen, E.O. (2010). Assessment of Insect pest and disease control by cocoa farmers in relation to their income in Kwara State, Nigeria Middle East Journal of scientific Research. 2010. 6(2) Pp.147-151.

United Nations Framework Convention on Climate Change (UNFCCC). (2007). Climatic Change Impact, Vulnerabilities and Adaptation in Developing Countries UNFCCC Secretariat, Martin-Luther-King-Straat 853175 Bonn, Germany. http;//www.unfccc.int

Yusuf, T.M. (2000). Socio-Economic Analysis of poverty level among rural dwellers in Kwara State, Nigeria. Unpublished M.Phil thesis in the Department of Agricultural Economics University of Ibadan, p.122

Ziervogel, G., A. Nyong, B. Osman, C. Conde, S. Cortes, and Dowing, T. (2006). Climate variability and change: implications for household food security. Assessments of Impacts and Adaptations to Climate Change (AIACC) Working Paper No. 20, January 2006. The AIACC Project Office, International START Secretariat, Washington DC,USA.

Zoellick, Robert, B. A. (2009). Climate Smart Future. The Nation Newspapers. Vintage Press Limited, Lagos, Nigeria. P.18. 